\title{
Weapons of Mass Defamation: Aspects of the 2006 'Cartoon Crisis'
}

MIKAEL ROTHSTEIN

University of Copenhagen

\begin{abstract}
The so called 'cartoon crisis' that arose in the wake of the publication of twelve satirical drawings of the Prophet Muhammad has been discussed in numerous ways. So far, however, the debate has not included a deeper analysis of why the desecration of Islam's prophet ignited such a response. Contrary to the claims of Islamic dogmaticism, the attributions regarding Muhammad's properties as a human being in Islamic culture in certain ways supersedes the cult for Allah. Muhammad is perceived as the perfect human being, and everything good about humanity consequently has Muhammad at its root. The disfavouring of Muhammad therefore is the disfavouring of any Muslim and of humanity as such. The article argues that the cartoons were interpreted more than anything else as a mockery of human dignity, and that the response was in defense of that rather than of Islamic dogmaticism.
\end{abstract}

Keywords: Prophet Muhammad, cartoons, Islam, media, conflict

In this article I propose a partial interpretation of the so called 'cartoon crisis' of 2006 that points to hitherto underemphasized aspects of the entire affair. The general perception of Islam and Muslims, whether among the public or in academia, is very often caught up in perspectives defined by traditional Islamic dogmatism; religion, however, is much more than formal theological teachings, and there are no reasons why the scholarly approach should abide by the standards set by religions. In this article I restrict my presentation to a closer look at the mythological basis for the way so many Muslims responded - i.e., the narratives, ideas, and concepts that underlie 
general reactions in the Muslim world. My attempt, which builds on a general phenomenological approach to the concepts of religious imaginations and worldviews in relation to Islam, is simply to identify some of the conceptual preconditions for the reactions we saw. What I am proposing is an explanation of why some Muslims around the world became very angry; but also, more importantly, why most Muslims felt frustrated and sad when they realized that their prophet had been ridiculed. In the 'cartoon crisis', this extremely diverse, globally scattered group of people responded with the same kind of feelings and sentiments to the desecration of their prophet, and the historian of religions was offered a rare opportunity to examine what quite obviously is central to most - if not all - of them. As always the study of religion is the study of people, and people only.

First, however, I describe the main events that took place. ${ }^{1}$

\section{A Brief Outline}

It would be wrong to consider 'the cartoon crisis' as a separate, isolated phenomenon. Rather, it was an incident amplified by an already prevailing societal condition. When the Danish newspaper Jyllands-Posten commissioned a number of cartoonists to portray Islam's prophet Muhammad, it was, in my judgement, yet another example of the disfavouring of that particular religion, which is seen by many people in Denmark - not least nationalists and neo-conservatives - as a negative influx into society. The newspaper, however, maintains that the cartoons were printed in defense of freedom of expression. This is quite true, but it is not the whole story.

The situation is complex, but scepticism towards Islam has the following background: Most importantly the increasing immigration of Muslims into Europe and the social problems it entails, secondly the global climate of suspicion towards Muslims due to the last five or six years' rise of international terrorism. In effect, it has become commonplace to express negative expectations regarding Islam in public, and it remains a problem for many Muslims to find a fruitful and constructive position in Western societies. It would be wrong, however, to place all responsibility for this situation on an unfriendly or xenophobic Danish society. There are highly problematic ideological and political structures in certain parts of the Islamic communi-

\footnotetext{
${ }^{1}$ As I am no specialist in Islam, I am unable to offer a comprehensive analysis of the many theological traditions throughout the world that have expressed different interpretations of the events described in the article's first section. What I have tried to do is to draw a general picture of the basic features that, as I see it, permeate Islamic mythology and theology with regard to the so called cartoon crisis. Sometimes historians of religions should allow themselves to comment on things outside the narrow scope of their special field. This is such a time.
} 
ties in Europe that obviously play an important role. But the present political climate in Denmark definitely explains why Jyllands-Posten decided to print the cartoons.

The concrete backdrop of what transpired before the publications of the cartoons is particularly important. The cartoons were published in reference to a very specific incident which in principle remains relevant without regard to the cartoons themselves: A Danish author, Kaare Bluitgen, known for his persistent criticism of the influence of hard-core Islamists in certain areas of Copenhagen, had prepared a manuscript about Muhammad and the birth of Islam aimed at a young readership. When his publisher asked a few artists to illustrate the book, nobody - so the public was told - dared to take on the job. Considering the Islamic theological reluctance or prohibition against portrayals of Muhammad, they feared reactions from conservative Muslims. After all, Europe had witnessed assassinations and severe threats in other cases where artists, authors and filmmakers had challenged Islam. Later it appeared that many other artists, who would have accepted the job, had never been asked, but the case as it appeared in the media was quite clearcut: the illustrators were being held back by pressure from certain Islamic groups - freedom of expression was being suppressed due to an unacceptable religious threat.

The situation was highly disturbing to most Danes, who are simply not in the habit of allowing religious sentiments to set the standard of what one can say or publish. Everybody - including religious individuals - can express whatever they wish, within the limits of a highly liberal and dynamic legislation.

The country's largest newspaper, Jyllands-Posten, known to support the current Danish neo-conservative government, was the first to print the story, and it was decided that the newspaper should make a point out of contesting the situation. A number of cartoonists were approached, and asked to portray Muhammad to state that in this country we take freedom of expression seriously. And indeed we do. I know of no single voice in the debate that said otherwise, not among majority Danes, neither among Muslims.

The cartoonists were given free hands and were promised that any representation they would come up with would be printed in the paper in order to celebrate the unconditional freedom of expression. Twelve cartoons were delivered to the editor, but a number of those who had been asked rejected the invitation. Some of the latter have explained that they found it ridiculous, others that they were simply uninterested in the job. Be this as it may, the results were extremely different. A few were sinister, some critical, 
a few were rather neutral, some funny, one hardly understandable, and a few in fact took a stand against the newspaper's strategy. ${ }^{2}$

\section{What Happened: In a Very Few Words}

What happened after the publication of the cartoons is indeed a long and complex story. For details and references I refer to the sources mentioned in the footnotes. In the following (brief) outline I shall including some of my own considerations.

To put if briefly: the cartoons triggered a series of angry reactions in the Muslim world. In extreme cases people in Islamic countries took to violence and unfortunately more than a hundred people died. Most remarkably the Danish Consulate in Damascus, Syria, was attacked and destroyed. The general picture, however, was one of protests in the streets and proclamations by both governments and religious organisations. Diplomats complained, and trade relations were suspended by bans. Denmark was seen as a sinister and cruel example of the anti-Islamic West at its worst. Some reactions were quite obviously instigated by various governments, but in many other cases the reactions were sincere. Be this as it may, Muslims around the globe demanded an apology from the Danish government. Others wanted the government to intervene and shut down Jyllands-Posten, and some insisted that the newspaper's editors and the cartoonists be arrested and punished. Some even demanded capital punishment.

The government, of course, has no control over the media in Denmark, and capital punishment is a thing of the remote past. From the viewpoint of the Danish political and legal system, these reactions were absurd and unrealistic. But the dramatic reactions raised two questions of principle in the West: to what degree should religious arguments be voiced in public, and should freedom of expression remain virtually unlimited? The incident, unsurprisingly, also added force to the ongoing debate about Islam in Denmark: the spotlight was focused on the encounter between Islam and 'the West', but most importantly on the conflict between the secular ways of Danish society and the new demands from religious groups.

\footnotetext{
${ }^{2}$ All this is described and discussed in a number of books that were published in the wake of the crisis. For documentation and further details the reader is refered to Bech Thomsen 2006, Christoffersen 2006, Folke Kaarsholm 2006, Hundevadt \& Hansen 2006, Jerichow \& Rode 2006, Rothstein \& Rothstein 2006, Seidenfaden \& Engelbreth Larsen 2006, Trads 2006, Jensen 2006 and Repp 2006 (Repp has a thorough historical outline of the event, while Jerichow \& Rode provide all essential sources). There are also a number of internet sites available, as the conflict ignited a global response that is still developing. One such site, linking to numerous others, is http://www.zombietime.com/mohammed_image_archive/.
} 
In the public discussion two positions emerged. One of these claimed that Muslims (or for that matter people of other faiths) have to understand that criticism or satire regarding religion belong to an open, democratic society, and that they simply have to accept it. There should be no stepping back. The other position insisted that we need to be more sensitive and disciplined in the way we treat one another, not least when it comes to religious or ideological differences. Consequently, many people supported the Danish government's rather hardline strategy of total denial and refusal of responsibility, while others felt that this 'stand firm' policy simply made the problem escalate. Others expressed solidarity with those who felt offended and questioned the behaviour of Jyllands-Posten. A middle position, which I argued in Rothstein \& Rothstein 2006 (the first book on the crisis to appear), was that the freedom of expression is non-negotiable, but that it should be used wisely and sometimes in the interest of society at large. It was - and is - my impression that Jyllands-Posten's project of printing the cartoons is from a legal point of view totally unproblematic, but also that it was an unwise thing to do: not because discussion about Islam or criticism of Muslims should be avoided, but because the provocation distracted the debate from important issues and took it into the realm of severe conflict.

In the aftermath of the crisis it became clear that a lot of spin, deception and manipulation had taken place: Islamic organisations in Denmark and abroad had been manipulating data, key individuals had effectively managed to influence things outside the public eye, editors had held back information, politicians of all sorts had made a mess out of everything, civil servants had acted as if blindfolded while bizarre accusations were building up, and lies about Denmark had been circulated in the Muslim world. People were indeed being betrayed by their leaders in many Muslim countries, and let down in many ways in Denmark. The case brought forth some of the most destructive sentiments in the Islamic world. As mentioned, property was destroyed, embassies set on fire, boycotts made effective, commercial relations terminated, and many jobs lost. Nobody was innocent. The 'cartoon crisis' was a good example of what happens when all parties effectively avoid communicating with each other or seeking understanding, and reject any attempt at reconciliation.

The conflict only developed the way it did due to outspoken ill will on both sides. The crisis, I believe, could have been solved on the political level with no major difficulties if the Danish government had employed another strategy, based on sound information about Islam and the recognition of alien cultural ways as something to be taken seriously. Muslim leaders in many countries had a similar possibility to downscale the conflict, being 
well aware of ways and conditions in the West, but they acted too late and not at all as potently as one could have wished. Sadly, the conflict merely widened the gap between different groups in Danish society, and at least temporarily made relations between the Islamic world and the West in general more complicated. Scholarship about Islam had never been more needed in politics and in the public sphere, but ignorance remained the prevailing driving force.

On 26 October 2006 the case came to a legal pause when a local Danish court ruled in favour of Jyllands-Posten, stating - to nobody's surprise - that no law had been violated by the publication of the cartoons. A group of Danish Muslims had taken the case to court, claiming that the newspaper had acted against laws and regulations that prohibit blasphemy and defamation of religious or ethnic groups. However, as is normal in Danish courts, the protection of freedom of expression and of freedom of the press was considered to be more important. So far the only noticeable reaction has been the departure from Denmark by one imam, who had declared that if the court ruled in favour of the newspaper he would leave he country and never return. Today, strangely, the debate is almost absent, and when it does occasionally pop up every now and then nothing new is added. The bulk of the literature that emerged in the wake of the affair sold only very moderately. Analysis and documentation does not appeal very much. The only books pertaining to Islam that are widely read in Denmark are those written by outspoken critics of Islam.

\section{Interpreting the Events: The General Pattern of Islamic Mythology}

In order to understand the Muslim reaction, we need to revisit what I shall term the general pattern of Islamic mythology. There is nothing in this that will surprise the historian of religions, but the deeper implications of the basic Islamic notions are very often downplayed or forgotten in the discussion. As I see it, the key to opening the case for further exploration lies in the mythological foundations of Islamic thought. My two premises are that due to basic Islamic mythological structures the defamation or disregard of Muhammad works as a defamation or disregard of any Muslim, and that individual or collective reactions of the kind we witnessed were in fact quite predictable. The cartoons, as I shall try to explain, were experienced as a humiliation of every Muslim and of human dignity in general. The drawings did not offend against Islamic dogmatism as much as they offended millions of people's experience of themselves as moral individuals and decent human beings. In order to understand Muslim reactions, we thus need to 
reconsider Islam's basic myths and examine more closely what they entail regarding 'the human'.

\section{The Double Mythological Axis}

Islamic mythology forms a double axis, where the vertical is the transmission of divine intent, and the horizontal the distribution of the divine message. The myth of how Allah revealed the Qur'an is, from a theological perspective, perceived as the most important, and the external assessment of what Islam is all about will normally pay most attention to this particular narrative. However, there are reasons to reconsider this approach. As I see it, in order to interpret what is essential to an Islamic worldview, the actual focal point might equally well be the person Muhammad. Indeed things are interconnected in all possible ways, but in our analysis we may nevertheless distinguish between a traditional 'Allah-centric' approach, and a study that departs from - and ends with - the person Muhammad. While Islamic theology places Muhammad below Allah, I shall for heuristic reasons do the opposite.

Allah, the creator god who holds universal insight and universal power, has - according to Islamic theology - chosen Muhammad as his prophet. Muhammad, consequently, is in all ways the one who has shown the path to Allah. Human beings have no other real access to the divine being apart from that brought about by Muhammad. One dimension of this path is the revelation itself, the Qur'an. Another is Muhammad himself, as his ways in life are interpreted as the ideal expression of what a human being should be like. The Qur'an itself makes a point of this and relates respect and love for Muhammad to the highest religious aspirations (sura 33:22). The idea is that Muhammad lived a perfect life because he was in perfect alignment with the divine will as it is expressed in the Qur'an. Hence the hagiographic hadith and sira literature, that forms a parallel to revealed scripture by highlightening the ways in which Muhammad in his everyday life turned divine rules into practical actions. As the myth of the revelation unfolds, Muhammad remains at the centre, and the human ideal exposed through his sunna appears simultaneously. The legends tell of a man who, from his early youth, longed for enlightenment, a seeker with no precise understanding of what he was seeking. According to one famous story, Muhammad was once approached by angels, who purified him by washing away a black spot form his heart; thus they prepared him for his subsequent mission as Allah's prophet. (The story is well known from Ibn Hisham's rendering of Muhammad's youth, and is indicated in sura 94:1.) In mythological terms, 
he was initiated to serve as the mediator between the only god and humanity, a position held in principle by other prophets before him, but not to the same degree and certainly not with the same implications: Muhammad was the first to receive the ultimate revelation. According to Islamic tradition Muhammad went into solitude every now and then to contemplate, and eventually he achieved what he was longing for: on behalf of Allah the angel Jivril revealed himself to Muhammad, who gradually came to understand his own true identity as a prophet and thus his mission.

Narratives such as these were taken down and transformed into important religious texts during the first three centuries after the formation of Islam. The writings by compilators and editors such as al-Bukhari (d. 870), Muslim (d. 875), Abu Dawud (d. 888), Ibn Hisham (d. 834) and others subsequently became de facto canonised and thereby came to reinforce the celebration of the prophet that lives on today. Muhammad is inscribed as a core symbol in Islam, and has been so from the first instance.

In terms of Islamic dogmatism Allah is the active part, but as the story goes Muhammad is in fact also a driving force. He strives to get to know 'the truth' and struggles to overcome his personal religious longings and doubts; most importantly, he places himself at the disposal of the (to him as yet unknown) divine powers (as recollected by A'isha in al-Bukhari's collection). Muhammad was not simply waiting. He was, on the human level, instrumental in the process of making the revelation happen. Furthermore, according to hadith, Muhammad was throughout his life socially and morally in accordance with Allah's guidelines even before the advent of Islam, i.e. before the revelations commenced. In one famous account (al-Bukhari, Vol. 1, book 1, no. 3), Muhammad's wife, Khadija, receives him shortly after his first encounter with Allah's messenger angel (sura 96:1-3). Muhammad, confused and frightened, says:

'I fear that something may happen to me.' Khadija replied, 'Never! By Allah, Allah will never disgrace you. You keep good relations with your Kith and kin, help the poor and the destitute, serve your guests generously and assist the deserving calamity-afflicted ones.'

The concept of hanif is applied to people who, prior to Islam, recognized the dogma of monotheism. For instance, in the Qur'an Ibrahim carries this designation (sura 3:68), and in principle the same can be said about Mohammad before he became aware of Allah more directly. Before the revelation took place, he in fact represented the Islamic ideal as far as his human limititations would allow. 
Muhammad is in all ways the link between the divine and the human. By designating Muhammad 'the Seal', the last of prophets, it is stated that all knowledge has hereby been made available, and that no further revelation is needed. This does not mean that the intellectual history of humanity ends, but it does mean that any subsequent understanding must be based on the foundation provided by the revelation and by Muhammad's example. Nor has history come to an end; since the Qur'an was given to Muhammad, however, the conditions for any historical development have changed. The revelation is a unique milestone, and the facilitator is in every respect Muhammad.

The world prior to Muhammad and the world we are living in today are not the same. Muhammad has provided an entirely new condition, partly by handing over the Qur'an to humanity, but also by being himself: the perfect individual, the first human being ever to be in full accordance with the divine intention. With Muhammad, what it means to be human has reached its ultimate state. In a way true humanity did not exist between the wreck of the original ideal, when Adam and Hawwa failed to meet Allah's expectations (sura 2:36), and the realisation of Allah's will by Muhammad. Thus Muhammad is inscribed in Islam's mythological narrative as the renewer of human ideals, in effect as the first realized human being ever.

The institutionalisation of Muhammad, however, has more layers. Theologically the most important ones have to do with his function as a prophet, but narratives about him also have a popular dimension that celebrates Muhammad in a much more concrete way. These narratives allow the devoted Muslim to encounter the prophet on a very tangible, everyday, ordinary level, where his bodily appearance and general conduct are emphasized. The theological term for this interest in - or rather meditation upon-Muhammad's looks is shamail, translated as 'outward form', but also comprising themes such as behavior, character, temperament, and attitude. All in all, shamail in relation to Muhammad is 'a term used to describe the details of the kind of life the Prophet (saas) led and his personality traits'. ${ }^{3}$ A presentation for a childrens' book, Life of Perfection: Shamail of Rasulullah, about Muhammad reads as follows:

Designed to develop a special love and respect for the Prophet (s) in the minds and hearts of children, this unique textbook chronicles his personality, habits, and daily activities. ${ }^{4}$

\footnotetext{
${ }^{3}$ See: http://www.harunyahya.com/prophetmuhammad04.php (May 14th 2007)

${ }^{4}$ See: http://www.astrolabe.com/product/1951/Life_of_Perfection:_Shamail_of_Rasulullah. html (May 25th 2007)
} 
The shamail-related narratives, carried by a characteristic discursive strategy, invite everybody to join in the celebration of the prophet. The following, from a hadith presented by Abu Isa at-Tirmidhee (d. app. 892) is a good example:

Whoever unexpectedly saw him would stand in awe of him, this due to his exceptional descriptions, his heavenly sense of gravity, dignity, and appearance and deluge of spirituality. Whoever accompanied him and got to know him would love him, to the point that that he became more beloved to him than his father, his child and indeed the whole of mankind. This was due to the clear manifestation and existence of all that would necessitate love such as perfect morals and manners, sweeping compassion and kindness, innate humility and his captivating hearts and uniting them... ${ }^{5}$

One aspect that is often mentioned is the prophet's physical appearance and beauty, and quite often details are discussed in order to identify the precise nature of his looks. It is not enough to ponder his function as Allah's prophet, and theologians will go to great length to resolve doubts or disagreements regarding Mumammad's looks. The hadith-text Shamail al Muhammadiyyah ('Description of Muhammad') (part 1) also from Abu Isa at-Tirmidhee, which deals with Muhammad's height, reads:

The Messenger of Allâh, sallAllâhu 'alayhi wa sallam, was neither very tall, such that he would be clearly noticed, nor was he short,' (Q) Meaning that he was of medium height. His being short has been categorically negated but only his being so tall as to be clearly noticed has been negated, in this lies an indication that he, sallAllâhu 'alayhi wa sallam, was indeed of medium height but leaning towards being described as tall and this is what has been reported about him, sallAllâhu 'alayhi wa sallam, by al-Bayhaqî. There is no contradiction between this and the forthcoming description that he, sal1Allâhu 'alayhi wa sallam, was of medium stature because such a statement is relative. This understanding is strengthened by the report of al-Barâ'a, ‘He, sallAllâhu 'alayhi wa sallam, was of medium stature but closer to being described as tall. ${ }^{[2]}$

al-Bayhaqî and ibn `Asâkir mention that

\footnotetext{
${ }^{5}$ See: http://www.allaahuakbar.in/article_showall.asp?cat_id=228\&parent_id=8\&parent_na me $=$ Scholars $+\% 26+$ Mashaykh\&sub_name=Imaam+Aboo+\%92Eesaa+at-Tirmidhee+(Rahima hullaah) (May 25th 2007).
} 
None would be perceived to be taller than he, sallAllâhu 'alayhi wa sallam, sometimes two tall men would stand on either side of him and he would seem taller than them, yet when they parted he would seem to be of medium height.' ${ }^{[3]}$ Ibn Saba', al-Khasâ' is, mentions that when he, sallAllâhu 'alayhi wa sallam, sat, his shoulder was higher than all those sitting around him. It is said in explanation to this, 'Perhaps it was that none could be perceived to be physically above him just as none was spiritually and morally above him. ${ }^{6}$

In this section Muhammad's role as the messenger of Allah is of course indirectly implied, but it is his body that comes into focus. It is the person, the human being Muhammad, that is of interest. In a subsequent section (6) it is said that Muhammad 'was not extremely white and neither was he very brown'; immediately after this, his hair is described:

His hair was neither very curly nor completely straight', (M) Meaning that his, sallAllâhu 'alayhi wa sallam, hair was in a state in between being very curly and completely straight and the best of affairs are those that are in between the two extremes. az-Zamakhsharî said, 'The predominate course amongst the Arabs is to have curly hair and among the non-Arabs, straight hair.' Allâh has blessed His Messenger, sallAllâhu 'alayhi wa sallam, with the best of virtues and qualities and has combined in him all that He has scattered amongst the different races. ${ }^{7}$

Once again the hadith offers what is almost a meditation upon details of Muhammad's body, but not only that: starting from his physical appearances, it is stated that he represents a universal human ideal, and therefore that humanity is unified in him. Many similar examples can be given. In each case Muhammad is isolated from the writer as well as the reader in time and space, but the text nevertheless strives to create a plastic, tangible and almost sensual impression of the man. We need to consider what role this emphasis on the prophet's social ways and bodily features plays in the fabric of Islamic mythology and theology, not only to appreciate the dynamics of Islamic ideas but also, as we shall see below, to comprehend the case before us, the 'cartoon Crisis'.

From a theological, dogmatic point of view Muhammad is not emphasized to the same degree as the power and nature of the creator god, but from an etic position Muhammad, as indicated above, stands out as the more

${ }^{6} \mathrm{http}: / /$ www.allaahuakbar.in/article_read.asp?id=350

7 http://www.allaahuakbar.in/article_read.asp?id=350 
important character. No communication to the divine escapes Muhammad: it was he who channelled the revelation, who provided instructions regarding proper ritual conduct, and who identified moral virtues. The history of how Islam originated as a new religion has Muhammad as the single most important agent. During the 'cartoon crisis' this was not explicitly stated by the thousands upon thousands of affected people in the Islamic countries, but it was instantly clear that their reactions had to do with the status attributed to Muhammad rather than with Allah or Islam's theological dogmatism.

It is important to note that the very belief in Allah presupposes a trust in Muhammad, the kind of trust that is created and maintained by means of hadiths such as those previously mentioned. The only reason why humans are aware of Allah today is the fact that Muhammad told about him, which means that what Muhammad said has to be true if Allah is true. Or, vice versa: if Muhammad was lying, Allah cannot be. The belief in Allah, therefore, cannot exist without a corresponding trust in Muhammad - a fact stated with simple beauty in the Islamic credo. And so the circle ends: Allah is the dogmatic point of departure, but Muhammad is the creator of that particular point - or, in terms of Islamic theology, he who has brought humanity to that point. Holding that position, he cannot be just 'anyone', either as a social character or as a physical human being. Allah has chosen him because of his remarkable human qualities, and by serving as Allah's prophet these qualities merely developed further and took him to the highest possible human standards.

While Muhammad was alive he carried this authority himself, but after his death his charisma was gradually transferred to new media; to use Max Weber's well-known terminology, it was routinized. It is normal, and obvious, to interpret the abundant hadith and sira literature as the prime mechanism in this connection, as these texts describe the life and work of Muhammad in minute detail, and because the texts are effectively consulted for guidance with respect to Muhammad's example. Similarly, Islamic law, the sharia, builds upon traditions that can be traced back to what Muhammad allegedly said or did in certain situations or regarding certain subjects. Furthermore, we may also interpret the Qur'an itself as a reflection of Muhammad, disregarding theological dogma. The very existence of the Qur'an reminds the reader of Muhammad, because it was facilitated by him and because he is mentioned (directly or indirectly) over and over again in the text. Moreover, it carries the blueprint not only of Allah's will, but also of Muhammad's virtues. Muhammad was, in Islamic terms, able to understand and appreciate the revelation better than anyone, and he therefore serves as 
the human embodiment of everything good and right, i.e. everything Allah wants from human beings. The Qur'an therefore points back to Allah as well as to Muhammad, but Allah is only known and approachable thanks to Muhammad's prophetic achievements. In this sense Muhammad remains the gateway to Allah, and - even if Allah is at the centre of everything - an inescapable figure in the system.

Even the Qur'an, as we have seen, helps to construct Muhammad as 'an excellent exemplar for him who hopes in Allah and the latter day and remembers Allah much' (sura 33:22), which, ideally, is any Muslim and thus any human being. This is important, because recognition of any religious system requires recognition of the authority that relates it. Teaching and teacher go together. Obviously it is necessary for the prophet to have an audience (Barker 1993). The category 'prophet' simply implies a social relation between the one who receives the revelation and those who believe him to be such a receptor or channel. One way of showing respect and acceptance with regard to the revelation or teaching, therefore, is to revere and honour the source of it, the religious leader. Thus Muhammad remains a precondition to Islam, while serving as the embodiment of humanity in the 'Era of Truth', i.e. the world since the inception of Islam.

Seen from this perspective, Muhammad becomes the mediator between the vertical structure of revelation and the horizontal level of distributing the message among humans. In all possible ways he occupies the position of the mediator, never transgressing the dogmatic understanding of what is divine and what is not, but certainly standing at the boundary between what is human and what is extraordinary or above the human. One remarkable example is the narrative of Muhammad's nightly ascension to the seven heavens (as derived from sura 17:1) where he certainly transcends the limitations of ordinary human beings. Other stories tell of his healing powers; some claim that Muhammad have Allah's permission to intercede on behalf of members of the ummah on the Day of Judgement. To the intellectual elite, however, the miraculous revelation of the Qur'an and Muhammad's infallibility remain the most important (Watt 1987, 146).

At any rate, as in the case of any other religious leader who claims to communicate with divine forces, Muhammad's historical appearance is mixed with all sorts of religious imaginations. He has become mythologized; this was inevitable. By claiming contact with divine entities he effectively entered the realm of religious fantasy, subjecting himself to mythologization and thus to a status different from that of any other human being. All this is usually summed up in a simple statement: Muhammad is seen as the 
remarkable, perfect individual, the extraordinary, perfect human being, but he is not himself divine. Needless to say this identification is fundamentally different from the emic perspective, where narratives about Muhammad are perceived as historical facts. ${ }^{8}$

\section{Implications?}

But what do these observations entail? And what does it mean in relation to the 'cartoon crisis'? As we have seen, the theological elaboration of Islamic mythology creates a balance between Allah and Muhammad that is distinct, yet blurred: Allah is divine, Muhammad is not, but at the same time Allah is only known and approachable due to the perfect human being, Muhammad, who serves as his prophet. In fact it seems as if Muhammad is an unavoidable prolongation of Allah, made necessary as a consequence of the god's divine nature. It is impossible to meet Allah, impossible to see him or even to understand him. Everything depends on him, while he depends on nothing. He can only be approached through a system of mediation. The Qur'an is the more concrete means, but the facilitator of the text, Muhammad, serves a parallel purpose; partly because he brought the text about, partly because his life serves as the ideal example of how one should live to be close to Allah. In short, Muhammad makes Allah approachable. He makes it possible for Muslims to be Muslims. He makes it possible for humans to be human.

The same argument also applies if turned around: Allah can be seen as a prolongation of Muhammad. The construction of a new religion always leads to reinterpretations of prevailing mythological figures or the construction of new entities. As a religious innovator Muhammad constructed Allah as the divine agent that legitimated his project.

While this way of seeing things obviously contradicts any Islamic theological understanding, it is in perfect alignment with what we know about religious leadership and the construction of mythological beings in emerging and new religions. This is why L. Ron Hubbard is the central object of devotion in Scientology, Maharishi Mahesh Yogi in Transcendental Meditation, George King in The Aetherius Society and Jesus in Christianity (Refslund Christensen 2005; Rothstein 2001, 184f.). The founder, the prophet, the leader is the point of departure, while the god or divine principle he or she claims

\footnotetext{
${ }^{8}$ There are of course intellectual Islamic scholars who will employ another and more critically inclined approach to the historicity of hadith and sira, but for most Muslims, and therefore in this connection, such speculations are not relevant.
} 
to represent becomes secondary in importance - even if it is promoted dogmatically as primary. Religious communities do not only build on more or less abstract beliefs. They also need very concrete cornerstones, and the bearers of religious authority, typically the religious leaders, are just that.

No matter what the perspective - emic or etic - the Islamic community, the ummah, must by necessity relate to Muhammad in very concrete ways. The hagiographic tradition, as expressed in the hadith literature, the sira tradition and other narratives, links the community to Muhammad's ideal and structurally places the social group in the correct position relative to Allah. The ummah denotes a unification of all Muslims because everybody adheres to the same ideas and ideals, but at a deeper level the ummah forms a unity because anyone relating to what Muhammad said or did is virtually sucked into a certain logic determined by the structure that forms Islamic mythology. Muhammad is also at the core of Islam's social realm. He is dead, yes, but nevertheless, thanks to the ongoing construction of him as the ideal, he is present in modern people's minds. People's everyday lives are constantly related to Muhammad's ideal, and his absence at one level is compensated by his presence at another. In fact he may be even stronger in his presence through narratives than he could ever be in person, just like any other religious leader, saint, prophet or saviour. The fact that he is physically absent means that he cannot disappoint his adherents. No concrete reality can interrupt the mythological historiography that systematically and tirelessly idealizes the founder of the religion. But, as the 'cartoon crisis' shows, the ideal that is established in mythological historiography may easily be provoked. Hence it was not Muhammad himself that was humiliated or affronted, it was the socially constructed historiography about him that was challenged by an opposing counter-narrative. The negative representation of Muhammad in the West has a very long history, but the Jyllands-Posten attack on the prophet was among the first to be globally distributed in a very short span of time.

\section{Islam's 'Radical Humanism'}

Interconnected with the religious interpretation of the individual Muhammad, Islam is permeated by a radical humanism that is very often overlooked or not recognized at all. In Europe, and thus in larger segments of Christian culture, humanism - not rarely leading to secularism - functions as an alternative to religion. Human beings have 'liberated themselves from religion' and taken on the responsibility for themselves and the rest of the world. Humanity has released society from the chains of religion, and it becomes 
very easy to interpret outspoken religious people or societies as pre-modern or still caught up in the blinded or narrow-minded ways of the past (Hastrup 1999). The radical humanism of Islam contradicts this perspective in all ways possible. Humanity is wholly realized and fulfilled not when people dissociate themselves from religion, but when they recognize Allah as the sovereign power and abide by his rules and regulations. Muhammad is the human ideal because he is the religious ideal and vice versa. Celebrating the human, in the case of Islam, implicates a celebration of the divine.

In Denmark, no doubt, humanism and secularism are very strong cultural components. Christianity certainly permeates society, and Christian activists in politics, the National Church, and private organisations do whatever they can to gain influence, but the public discourse is not in the least bound by religion, which is perceived as belonging to the private sphere. This in itself explains why most Danes were stunned by reactions in the Muslim world following the publication of the cartoons. How could religion cause such anger, people wondered? These reactions would perhaps have been easier to explain if the central mythological character in Christian mythology, Jesus, were compatible with Muhammad, but he is not. Unlike Mohammad, Jesus is constructed as a divine being, a man-god, and therefore not only a symbol of the ideal human but also as a manifestation of the godhead itself. Furthermore, the myth of Jesus is based on the notion that he appeared in order to suffer. The humiliation and torment he met with, according to the Christian texts, was part of the divine scheme. Muhammad, however, is constructed as powerful and victorious in every aspect. He is certainly not meant to be the victim of mockery. Indeed the Qur'an pointedly stresses that people tried to counteract him by telling lies and suggesting that he was a fraud (sura 25:5-6), but to no avail. He was destined to win here and now. When people expressed their sympathy with the Muslim minority in relation to the cartoons, it was at the level of principle. It probably takes a Muslim to wholly comprehend the implications of what it means to mock the prophet.

\section{Why This Reaction?}

At this point we may return to our main question: What more precisely made Muslims all over the world react so strongly to cartoons printed in a relatively small newspaper in a strange country far away? The answer, in my opinion, is that they were provoked in two different if related ways. At a rather superficial level, it is a simple insult to mock the core symbols of people's religion. At another level, however, Muhammad represents 
something that goes much deeper than being a symbol of Islam as such. The editors of the newspaper that printed the cartoons, Jyllands-Posten, never considered this deeper level, and it still remains a mystery to most Danes why the reactions were so strong.

As indicated above, this deeper level has to do with Muhammad as the ideal representative of everything human. Mocking him is to mock humanity, or rather, 'that which is human'. To the outsider with no knowledge of Islam, Muhammad is the man who founded the religion and who is believed to have said something Muslims find important. To Muslims, however, he represents every ideal, every moral virtue, every hope, every positive aspiration and everything that is true. Precisely because at an ideological, idealized level, whether institutionalized or not, people identify their personal as well as societal standards with his, the mocking of Muhammad strikes a very deep chord in the average Muslim mind set. The ridicule of Muhammad is the ridicule of the individual Muslim as well as the entire ummah.

The cartoons did not only hit Muhammad. They also hit the single Muslim individual. Those who took to the streets were defending their prophet, but they were perhaps primarily defending themselves as moral human beings. On one symbolic level the cartoons came to function as a device of social or moral destruction, indeed 'a weapon of mass defamation', as they found their way into some of the most fundamental semantics in Islamic ways of thinking about the human condition, and introduced what is otherwise unthinkable: an attempt to deconstruct everything good, moral, righteous and true.

In fact, astonishment and confusion were important dimensions in the Muslims' reactions. Perhaps this element can be interpreted as a collective experience of anomie, as described by Peter L. Berger; a condition where people are facing a reality that according to their basic assumptions about the world is impossible. Such a situation creates social disorder and psychological instability, which subsequently leads to outbreaks of anger and sorrow. Through these reactions the affected groups or individuals aim at recreating what has been destroyed. The threatened cosmology needs to be reconstructed. From this perspective the demonstrations and riots become elements in the reestablishment of a nomos, a consistent and meaning-producing world-system. (Berger 1967.)

In the current context, the cartoons were interpreted as a symbol of a much broader Western campaign against everything Islamic. The US-led war in Iraq, the war in Afghanistan, the general resentment of Islam in Europe, the so called war against terror (including the reports from Guantanamo 
and Abu Ghraib), and many other things are often interpreted as elements in a global strategy that is supposed to counteract Islam in many different ways, and the cartoons could easily be fitted into that pattern. In fact, mocking Muhammad could be interpreted as the prototypical Western insult and disfavouring of anything pertaining to Islam or the Muslim world. Bear in mind that the cartoons only reached the broader Muslim world because a group of imams from Denmark actively disseminated them, to show how badly they felt Muslims were treated in Denmark. Obviously they knew how the provocation would be received. The cartoons were deliberately introduced into an already prevailing conflict as a reinforcing symbol of the alleged Western resentment of Islam.

The reactions, consequently, would probably not have taken the course they did if the general political climate had been different. No matter how provocative the cartoons were, people's reactions were very much nurtured by the prevailing conflicts. The other precondition for the reactions we witnessed is the fact that the cartoons managed to affect the self-esteem of so many people on a very personal level. The reactions throughout the Muslim world were of course expressions of a collective anger, but this was also an anger felt by each individual in a more personal or private way because the cartoons directly affected the individual's self-perception. The focal point is human individual and humanity itself, although it is the character of Muhammad that is the actual topic of discussion.

\section{A Final Remark: Iconography}

It was not the fact that pictures were made that caused the anger, as it is often believed. Drawings of Muhammad are relatively rare, and religious images are generally prohibited on the basis of three theological arguments: in making images (and figures) the artist is imitating the creator god, which is prohibited; Allah himself cannot be depicted; and images may lead to 'idolatry'. Portraits of the prophet, however, are certainly not unseen and certainly not alarming to a degree that would explain the reactions. He can even be found on billboards in Shiite societies. It was the attempt to ridicule Muhammad that caused the pain and the anger. The problem is not one of iconography as such. It is about defamation and humiliation of the individual and society by means of what we may term 'counter-iconography'.

But does this mean that Islam's perception of Muhammad is fragile or even vulnerable? Is the system so weak that people have to respond so fiercely to an insult such as the cartoons? Probably not. On the contrary: the strong reactions could be interpreted as an expression of power and control. 
This is where most Muslims would draw the line, because Muhammad, at the symbolic level, refers to everything they hold dear, and to themselves as human beings. The notion of Muhammad as the key symbol of everything good, and thus of the belief in the revelation and the confidence in Islam, was probably reinforced by the conflict. If so, Jyllands-Posten's strategy of provocation totally failed.

Bibliography

\section{Barker, Eileen}

1993 Charismatization: The Social Production of 'an Ethos Propitious to the Mobilisation of Sentiments'. - Eileen Barker \& James A. Beckford \& Karel Dobbelaere (eds), Secularization, Rationalism and Secterianism, 181-202. Oxford: Clarendon Press.

\section{Bech Thomsen, Per}

2006 Muhammed-krisen - hvad skete der? Hvad har vi lært? Copenhagen: People's Press.

\section{Berger, Peter L.}

1967 The Sacred Canopy. Elements of a Sociological Theory of Religion. New York: Anchor Books.

\section{Christoffersen, Lisbeth (ed.)}

2006 Gudebilleder. Ytringsfrihed og religion i en globaliseret verden. Copenhagen:Tiderne Skifter.

Folke Kaarsholm, Lotte (ed.)

2006 Muslimsk-dansk dagbog. Copenhagen: Informations forlag.

\section{Hastrup, Kirsten}

1999 Viljen til viden. Copenhagen: Gyldendal.

\section{Hundevadt, Kim \& John Hansen}

2006 Provoen og Profeten - Muhammed krisen bag kulisserne. Copenhagen: Jyllands-Postens Forlag.

\section{Jensen, Tim}

2006 The Muhammad Cartoon Crisis: The Tip of an Iceberg. - Japanese Religions 31(2), 173-185.

\section{Jerichow, Anders \& Mille Rode (eds)}

2006 'Profet-affxren'. Et PEN-dossier om 12 Muhammed-tegninger - og hoad siden hændte: Dokumenter \& argumenter. Copenhagen: Dansk PEN. 


\section{Refslund Christensen, Dorthe}

2005 Inventing L. Ron Hubbard: On the Construction and Maintanance of the Hagiographic Mythology of Scientology's Founder. - James R. Lewis \& Jesper Aagaard Petersen (eds), Controversial New Religions, 227-258. New York: Oxford University Press.

\section{Repp, Martin}

2006 The Caricature of Caricatures: Communicational Strategies in the Danish Cartoon Conflict. - Japanese Religions 31(2), 129-162.

\section{Rothstein, Mikael}

2001 Gud er (stadig) blå. Copenhagen: Aschehoug.

Rothstein, Mikael \& Klaus Rothstein

2006 Bomben i turbanen. Copenhagen: Tiderne Skifter.

\section{Seidenfaden, Toger \& Rune Engelbreth Larsen}

2006 Karikaturkrisen. En undersøgelse af baggrund og ansvar. Copenhagen: Gyldendal.

\section{Trads, David}

2006 Islam i flammer. Danskerne og det muslimske oprør. Copenhagen: Høst \& Søns Forlag.

\section{Watt, W. Montgomery}

1987 Muhammad. - Mircea Eliade (ed.), The Encyclopedia of Religion, Vol. 10, 137-146. New York: Macmillan Publishing Company. 